\title{
Syntenic homology of human unique DNA sequences within chromosome regions 5q31, 10q22, 13q32-33 and 19q13.1 in the great apes
}

\author{
Rhea U. Vallente-Samonte, Robert A. Conte and Ram S. Verma
}

\begin{abstract}
Homologies between chromosome banding patterns and DNA sequences in the great apes and humans suggest an apparent common origin for these two lineages. The availability of DNA probes for specific regions of human chromosomes $(5 \mathrm{q} 31,10 \mathrm{q} 22,13 \mathrm{q} 32-33$ and 19q13.1) led us to cross-hybridize these to chimpanzee (Pan troglodytes, PTR), gorilla (Gorilla gorilla, GGO) and orangutan (Pongo pygmaeus, PPY) chromosomes in a search for equivalent regions in the great apes. Positive hybridization signals to the chromosome 5q31-specific DNA probe were observed at HSA 5q31, PTR 4q31, GGO 4q31 and PPY 4q31, while fluorescent signals using the chromosome 10q22-specific DNA probe were noted at HSA 10q22, PTR 8q22, GGO 8q22 and PPY 7q22. The chromosome arms showing hybridization signals to the Quint-Essential ${ }^{\mathrm{TM}}$ 13-specific DNA probe were identified as HSA 13q32-33, PTR 14q32-33, GGO 14q32-33 and PPY 14q32-33, while those presenting hybridization signals to the chromosome 19q13.1-specific DNA probe were identified as HSA 19q13.1, PTR 20q13, GGO 20q13 and PPY 20q13. All four probes presumably hybridized to homologous chromosomal locations in the apes, which suggests a homology of certain unique DNA sequences among hominoid species.
\end{abstract}

\section{INTRODUCTION}

Cytogenetic findings based on chromosome banding patterns have suggested similarities between great ape and human chromosomes while molecular data has further strengthened the concept of human descent (Luke and Verma, 1995). Fluorescence in situ hybridization (FISH) employing DNA probes has been used to analyze these genomes (Wienberg et al., 1990). Several composite DNA probes delineating chromosomal subregions and gene-specific loci have been constructed. The homology of subchromosomal regions and the reconstruction of intrachromosomal rearrangements in the genomes of closely related species can be achieved by comparative genomic hybridization (Arnold et al., 1996). In the present investigation, the locations of four human chromosome-specific DNA sequences have been identified in the chimpanzee, gorilla and orangutan and provide additional argument for the process of speciation leading to the descent of man.

\section{MATERIAL AND METHODS}

\section{Chromosome preparation}

Metaphase spreads were prepared from fibroblast cell lines of chimpanzee (AGO 6939A, Pan troglodytes, PTR) and orangutan (AGO 5252, Pongo pygmaeus, PPY) obtained from the Coriell Institute for Medical Research, Camden, NY, while a lymphoblast cell line of gorilla (CRL
1854, Gorilla gorilla, GGO) was obtained from the American Type Culture Collection (Rockville, MD, USA). Human chromosomes were prepared from PHA-stimulated lymphocyte cultures obtained from healthy individuals. The cultured cells were harvested using standard protocols (Verma and Babu, 1995).

\section{FISH}

The conditions for in situ hybridization were as described by Lichter et al. (1988). Briefly, chromosome preparations were dehydrated through an ethanol series and denatured in $70 \%$ formamide in $2 \mathrm{X} \mathrm{SSC}, \mathrm{pH} \mathrm{7.0,} \mathrm{at} 72^{\circ} \mathrm{C}$. The digoxigenin-labelled DNA probes used were as follows: chromosome 5q31-specific, chromosome 10q22-specific (HK1), Quint-Essential ${ }^{\mathrm{TM}}$ chromosome 13-specific (D13S585) and chromosome 19q13.1-specific (Oncor, Gaithersburg, MD, USA). Overnight hybridization was performed at $37^{\circ} \mathrm{C}$. Post-hybridization washes were done using $2 \mathrm{X} \mathrm{SSPE}, \mathrm{pH} 7.0$, at $70^{\circ} \mathrm{C}$. The probes were detected using fluorescein-labelled digoxigenin. Chromosomes were counterstained with DAPI/antifade and observed under fluorescent optics. Digital images were obtained using a cooled CCD camera (Oncor).

\section{RESULTS AND DISCUSSION}

Four chromosome-specific DNA probes were used to search for their equivalent positions in ape chromosomes. 

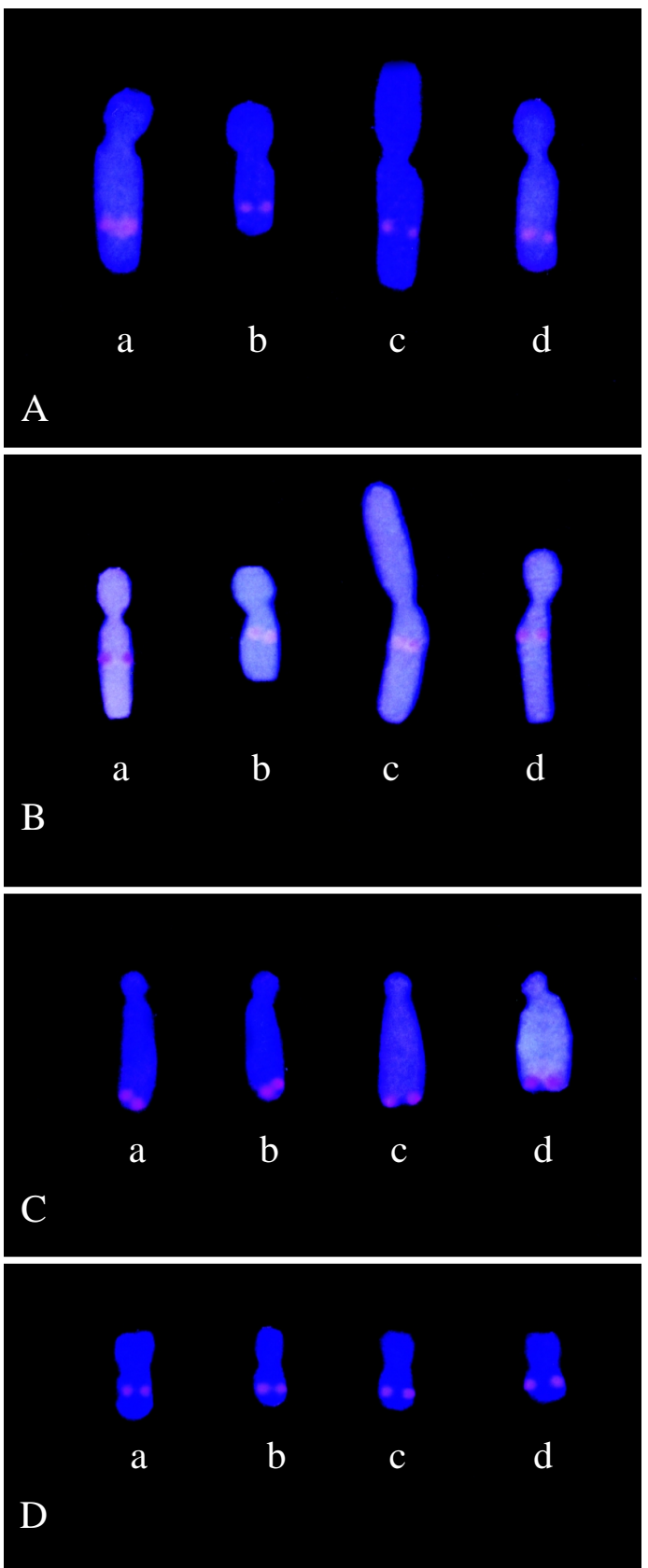

Figure 1 - Hybridization signals on (a) human, (b) chimpanzee, (c) gorilla and (d) orangutan chromosomes using the human chromosome-specific [A] 5q31, [B] 10q22 (HK1), [C] Quint-Essential ${ }^{\mathrm{TM}}$ 13q32-33 (D13S585) and [D] 19q13.1 DNA probes.
The chromosome 5q31-specific DNA probe contains a pool of 15 probes that commonly map to cytogenetic band $5 \mathrm{q} 31$ (Oncor, Inc.). The chromosome 10q22-specific DNA probe hybridized to sequences of the HK1 locus of human chromosomes. The Quint-Essential ${ }^{\mathrm{TM}} 13$-specific DNA probe (D13S585) hybridizes to chromosome bands 13q32-q33. The chromosome 19q13.3-specific DNA probe hybridized to band 19q13.1 of human chromosomes. We compared the hybridization signals of these chromosomespecific DNA probes on great ape metaphase chromosomes. Under the hybridization conditions used, the probes showed equally strong fluorescent signals at homologous positions in ape chromosomes, based on standard nomenclature (ISCN, 1985) (Figure 1). The summary of localization sites using the DNA probes is presented in Table I.

Chromosome band $5 \mathrm{q} 31$ has been correlated with the gene cluster encoding for the cytokines interleukin-13 (IL13) and interleukin-4 (IL-4) (Dolganov et al., 1996). Deletion of this band has been used frequently in the diagnosis of myeloid disorders (Paietta et al., 1987; Chandrasekharappa et al., 1990), and has been linked to susceptibility genes for bronchial hyperresponsiveness and asthma (Levitt and Holroyd, 1995). Several translocation breakpoints conferring leukemia have also been observed in this region (Sharp et al., 1987; Nakagawa et al., 1991; Knuutila et al., 1993). Chromosome band 10q22 contains the gene cluster encoding glutamate dehydrogenase (Anagnou et al., 1993) and the glycoprotein prosaposin (Bar-Am et al., 1996) and duplications and/or translocations have been reported in this region in humans. The excision repair gene ERCC5 has been localized within bands 13q32-q33 (Takahashi et al., 1992). The mapping of chromosome 13 has recently been completed (Hawthorn et al., 1994). Chromosome band 19q13.1 has been implicated in malignant hyperthermia (McCarthy et al., 1990; Deufel et al., 1995) and autosomal recessive congenital nephrotic syndrome of the Finnish type (CNF) (Mannikko et al., 1995; Fuchshuber et al., 1996). This region also contains the kallikrein gene family, which encodes the prostate-specific antigen (PSA) (Sutherland et al., 1988), and the human brain $\mathrm{Na}^{+}$-dependent inorganic phosphate $\left(\mathrm{P}_{i}\right)$ cotransporter (hBNPI) (Ni et al., 1996). These findings may serve as phylogenetic parameters in establishing an animal model for human diseases.

Table I - Summary of localization of chromosome-specific DNA probes in the great ape species.

\begin{tabular}{|lcccc|}
\hline $\begin{array}{l}\text { Chromosome- } \\
\text { specific DNA probe }\end{array}$ & \multicolumn{4}{c|}{ Chromosomal assignment } \\
\cline { 2 - 5 } & $\begin{array}{c}\text { Homo sapiens } \\
\text { (HSA) }\end{array}$ & $\begin{array}{c}\text { Pan troglodytes } \\
\text { (PTR) }\end{array}$ & $\begin{array}{c}\text { Gorilla gorilla } \\
\text { (GGO) }\end{array}$ & $\begin{array}{c}\text { Pongo pygmaeus } \\
\text { (PPY) }\end{array}$ \\
\hline $5 \mathrm{q} 31$ & $5 \mathrm{q} 31$ & $4 \mathrm{q} 31$ & $4 \mathrm{q} 31$ & $4 \mathrm{q} 31$ \\
$10 \mathrm{q} 22$ & $10 \mathrm{q} 22$ & $8 \mathrm{q} 22$ & $8 \mathrm{q} 22$ & $7 \mathrm{q} 22$ \\
Quint-Essential & $13 \mathrm{qM} 32-33$ & $14 \mathrm{q} 32-\mathrm{q} 33$ & $14 \mathrm{q} 32-33$ & $14 \mathrm{q} 32-33$ \\
$13 \mathrm{q} 32-33$ & $19 \mathrm{q} 13.1$ & $20 \mathrm{q} 13$ & $20 \mathrm{q} 13$ & $20 \mathrm{q} 13$ \\
$19 \mathrm{q} 13.1$ & & & &
\end{tabular}


Fluorescence in situ hybridization (FISH) using locispecific probes has been used to identify intrachromosomal changes based on DNA homology and has provided a powerful tool for studying karyological and genomic evolution (Muller et al., 1996). Our observations based on DNA hybridization experiments with great ape chromosomes indicate that a syntenic homology has been preserved in these regions during the course of hominoid differentiation. The presence of functionally conserved segments in the corresponding ape chromosomes further supports the concept of evolution at the DNA sequence level.

\section{RESUMO}

Homologias entre os padrões de bandamento de cromossomos e seqüências de DNA em grandes macacos e humanos sugerem uma aparente origem comum para estas duas linhagens. A disponibilidade de sondas de DNA para regiões específicas de cromossomos humanos (5q31, 10q22, 13q32-33 e 19q13.1) nos levou a realizar hibridação cruzada com cromossomos de chimpanzé (Pan troglodytes, PTR), gorila (Gorilla gorilla, GGO) e orangotango (Pongo pygmaeus, PPY) em um pesquisa de regiões equivalentes em grandes macacos. Sinais positivos de hibridação para a sonda de DNA específica para o cromossomo $5 \mathrm{q} 31$ foram observados em HSA 5q31, PTR 4q31, GGO 4q31 e PPY $4 q 31$, enquanto que sinais fluorescentes usando a sonda de DNA específica para o cromossomo 10q22 foram notados em HSA 10q22, PTR 8q22, GGO 8q22 e PPY 7q22. Os braços de cromossomos apresentando sinais de hibridação para a sonda de DNA específica para Quint-Essential ${ }^{\circledR} 13$ foram identificados como HSA 13q32-33, PTR 14q32-33, GGO 14q32-33 e PPY 14q3233 , enquanto que aqueles apresentando sinais de hibridação para sonda de DNA específica para o cromossomo 19q13.1 foram identificados como HSA 19q13.1, PTR 20q13, GGO 20q13 e PPY 20q13. Todas as quatro sondas presumivelmente hidridizaram para locais cromossômicos homólogos nos símios, o que sugere uma homologia de certas seqüências únicas de DNA entre as espécies hominóides.

\section{REFERENCES}

Anagnou, N.P., Seuanez, H., Modi, W., O'Brien, S.J., Papamatheakis, J. and Moschonas, N.K. (1993). Chromosomal mapping of two members of the human glutamate dehydrogenase (GLUD) gene family to chromosomes 10q22.3-q23 and Xq22-q23. Hum. Hered. 43: 351-356.

Arnold, N., Stanyon, R., Jauch, A., O'Brien, P. and Wienberg, J. (1996) Identification of complex chromosome rearrangements in the gibbon by fluorescent in situ hybridization (FISH) of a human chromosome 2q specific microlibrary, yeast artificial chromosomes and reciprocal chromosome painting. Cytogenet. Cell Genet. 74: 80-85.

Bar-Am, I., Avivi, L. and Horowitz, M. (1996). Assignment of the human prosaposin gene (PSAP) to 10q22.1 by fluorescence in situ hybridization. Cytogen. Cell Genet. 72: 316-318.

Chandrasekharappa, S.C., Rebelslky, M.S., Firak, T.A., Le Beau, M.M. and Westbrook, C.A. (1990). A long-range restriction map of the interleukin-4 and interleukin-5 linkage group on chromosome 5. Genomics 6: 94-99.

Deufel, T., Sudbrak, R., Feist, Y., Rubsam, B., De Chesne, I., Schafer, K.L., Roewer, N., Grimm, T., Lehmann-Horn, F. and Hartung, E.J. (1995). Discordance, in a malignant hyperthermia pedigree, between in vitro contracture-test phenotypes and haplotypes for the MHS1 region on chromosome 19q12-13.2, comprising the C1840T transition in the RYR1 gene. Am. J. Hum. Genet. 56: 1334-1342.
Dolganov, G., Bort, S., Lovett, M., Burr, J., Schubert, L., Short, D., McGurn, M., Gibson, C. and Lewis, D.B. (1996). Coexpression of the interleukin13 and interleukin-4 genes correlates with their physical linkage in the cytokine gene cluster on human chromosome 5q23-31. Blood 87: 33163326.

Fuchshuber, A., Naiudet, P., Gribouval, O., Jean, G., Gubler, M.C., Broyer, M. and Antignac, C. (1996). Congenital nephrotic syndrome of the Finnish type: linkage to the locus in a non-Finnish population. Pediatr. Nephrol. 10: 135-138.

Hawthorn, L., Nizetic, D., Lehrach, H. and Cowell, J.K. (1994). Assignment of 55 novel cosmids to seven subregions of chromosome 13 using fluorescence in situ hybridization. Genomics 21: 248-250.

ISCN (1985). An International System for Human Chromosomal Nomenclature. Birth Defects Original Article Series. Vol. 21, No. 1. The National Foundation, New York, NY, pp. 95-107.

Knuutila, S., Alitalo, R. and Ruutu, T. (1993). Power of the MAC (morphology-antibody-chromosomes) method in distinguishing reactive and clonal cells: Report of a patient with acute lymphatic leukemia, eosinophilia, and t(5;14). Genes, Chromosomes Cancer 8: 219-223.

Levitt, R.C. and Holroyd, K.J. (1995). Fine-structure mapping of genes providing susceptibility to asthma on chromosome 5q31-q33. Clin. Exp. Allergy 25 (Suppl. 2): 119-123.

Lichter, P., Cremer, T., Borden, J., Manuelidis, L. and Ward, D.C. (1988). Delineation of individual human chromosomes in metaphase and interphase cells by in situ suppression hybridization using recombinant DNA libraries. Hum. Genet. 80: 224-234.

Luke, S. and Verma, R.S. (1995). Human (Homo sapiens) and chimpanzee (Pan troglodytes) share similar ancestral centromeric alpha satellite DNA sequences but other fractions of heterochromatin differ considerably. Am. J. Phys. Anthropol. 96: 63-71.

Mannikko, M., Kestaila, M., Holmberg, C., Norio, R., Ryyananen, M., Olsen, A., Peltonen, L. and Tryggvason, K. (1995). Fine mapping and haplotype analysis of the locus for congenital nephrotic syndrome on chromosome 19q13.1. Am. J. Hum. Genet. 57: 1377-1383.

McCarthy, T.V., Healy, J.M., Lehane, M. and Heffron, J.J. (1990). Recent developments in the molecular genetics of malignant hyperthermia: Implications for future diagnosis at the DNA level. Acta Anaesthesiol. Belg. 41: 107-112.

Muller, S., Koehler, U., Weinberg, J., Marzella, R., Finelli, P., Antonacci, R., Rocchi, M. and Archidiacono, N. (1996). Comparative fluorescence in situ hybridization mapping of primate chromosomes with Alu polymerase chain reaction generated probes from human/rodent somatic cell hybrids. Chromosome Res. 1: 38-42.

Nakagawa, H., Tanaka, S., Takashima, T., Shizumi, Y., Nishigaki, H., Horrike, S., Taniwaki, M., Misawa, S., Kashima, K. and Hironaka, T. (1991). Acute erythroleukemia with $\mathrm{t}(3 ; 5)$ accompanied by hepatocellular carcinoma. Int. J. Hematol. 54: 213-217.

Ni, B., Du, Y., Wu, X., DeHoff, B.S., Rosteck Jr., P.R. and Paul, S.M. (1996). Molecular cloning, expression, and chromosomal localization of a human brain-specific $\mathrm{Na}(+)$-dependent inorganic phosphate cotransporter. J. Neurochem. 66: 2227-2238.

Paietta, E., Papenhausen, P., Gucalp, R., Reed, J. and Wiernik, P.H. (1987). The 5q-deletion: Correlation of breakpoints with the immunophenotype of leukemic blast cells. Leukemia 1: 822-824.

Sharp, R.A., Robertson, J. and Heppleston, A.D. (1987). t(3;5)(q21;q31) in a myelodysplastic syndrome. Leuk. Res. 11: 629-633.

Sutherland, G.R., Baker, E., Hyland, V.J., Callen, D.F., Close, J.A. and Tregear, G.W. (1988). Human prostate-specific antigen (PSA) in a member of the glandular kallikrein gene family at 19q13. Cytogenet. Cell Genet. 48: 205-207.

Takahashi, E., Shiomi, N. and Shiomi, T. (1992). Precise localization of the excision repair gene, ERCC5, to human chromosome 13q32.3-q33.1 by direct R-banding fluorescence in situ hybridization. Jpn. J. Cancer Res. 83: 1117-1119.

Verma, R.S. and Babu, A. (1995). Human Chromosomes: Principles and Techniques. McGraw-Hill Inc., New York, pp. 8-14.

Wienberg, J., Jauch, A., Stanyon, R. and Cremer, T. (1990). Molecular cytotaxonomy of primates by chromosomal in situ suppression hybridization. Genomics 8: 347-350.

(Received February 25, 2000) 
